\title{
Potential for functional replacement of methanogenic bacteria by acetogenic bacteria in the rumen environment
}

\author{
P Boccazzi, JA Patterson \\ Department of Animal Sciences, 3-101 Lilly Hall, Purdue University, \\ West Lafayette, Indiana 47907, USA
}

Ruminal fermentation is influenced by interspecies $\mathrm{H}_{2}$ transfer in which methanogens enhance energy production by fermentative microorganisms by converting $\mathrm{H}_{2}$ to $\mathrm{CH}_{4}$. However, the energy contained in $\mathrm{CH}_{4}$ represents a 5 to $15 \%$ loss of apparent digestible energy loss to the animal and contributes to global methane emissions. The objective of our research is to determine if alternative $\mathrm{H}_{2}$-utilizing bacteria, acetogens are capable to replacing the interspecies $\mathrm{H}_{2}$ transfer function of methanogens when methanogens are inhibited. We have isolated several acetogenic isolates, $\mathrm{A} 10$ and $3 \mathrm{H}$, with low hydrogen thresholds (Boccazzi et al, 1993, Proc Conf Rumen Funct, 22-28). The purpose of this research was to determine if they could utilize $\mathrm{H}_{2}$ in a mixed culture system.

Serum bottles $(120 \mathrm{ml})$ containing $0.35 \mathrm{~g}$ ground alfalfa hay $(1 \mathrm{~mm})$ were inoculated with $10 \mathrm{ml}$ of a solution consisting of $60 \%$ anaerobic dilution solution: $40 \%$ fresh rumen contents from a cow consuming a $60 \%$ concentrate $: 40 \%$ corn silage diet. Bromoethane sulfonic acid (BES, $5 \mathrm{mM}$ ) was added to all serum bottles except the controls. Treatments were : control, control + BES, ${ }_{3} \mathrm{H}+\mathrm{BES}$ and $\mathrm{A} 10+\mathrm{BES}$, where the acetogenic cultures were added to give a final concentration of $4 \times 10^{8}$ acetogen cells $/ \mathrm{ml}$ under a $\mathrm{CO}_{2}$ atmosphere. Triplicate serum bottles for each treatment and time period were incubated at $37^{\circ} \mathrm{C}$ and shaken at $200 \mathrm{rpm}$. Hydrogen and $\mathrm{CH}_{4}$ concentration in the headspace was measured by gas chromatography using thermal conductivity.

$\mathrm{No} \mathrm{CH}_{4}$ accumulated in serum bottles where BES had been added which indicates that $5 \mathrm{mM}$ BES completely inhibited methanogenesis for up to $74 \mathrm{~h}$. Hydrogen concentrations at $12 \mathrm{~h}$ were lower for cultures containing added acetogens. High levels of $\mathrm{H}_{2}$ in the control of $12 \mathrm{~h}$ may have been due to low numbers of methanogens in the inoculum. Concentrations of $\mathrm{H}_{2}$ were lower for control bottles and bottles containing acetogens at 24 and $74 \mathrm{~h}$. Cultures containing acetogenic isolate ${ }^{3} \mathrm{H}$ consistently had lower $\mathrm{H}_{2}$ concentrations than cultures containing acetogenic isolate $A 10$. These data show that acetogens can functionally replace the role of methanogens in interspecies $\mathrm{H}_{2}$ transfer and that different levels of $\mathrm{H}_{2}$ control may be obtained by using different acelogenic cultures.

\begin{tabular}{lccccc}
\hline & \multicolumn{9}{c}{$\mathrm{H}_{2}(\mu \mathrm{M})$} & $\mathrm{CH}_{4}(\mu \mathrm{M})$ \\
\cline { 2 - 6 } Treatment & $\mathrm{Oh}$ & $12 \mathrm{~h}$ & $24 \mathrm{~h}$ & $74 \mathrm{~h}$ & $74 \mathrm{~h}^{1}$ \\
\hline Control & 10 & 166 & 16 & 0.5 & 258 \\
Control + BES & 8 & 171 & 112 & 23 & 0.8 \\
$3 \mathrm{H}+\mathrm{BES}$ & 8 & 48 & 12 & 2 & 1 \\
$\mathrm{~A} 10+\mathrm{BES}$ & 9 & 108 & 44 & 21 & 3 \\
1 Initial $\mathrm{CH}_{4}$ concentrations were less than $2 \mu \mathrm{M}$. &
\end{tabular}

